\title{
Effects of $N$ and $P$ Fertilizer Placement on Establishment of Seeded Species on Redistributed Mine Topsoil
}

\author{
WILLIAM J. MCGINNIES AND KENT A. CROFTS
}

\begin{abstract}
The effects of fertilizer on the establishment of seeded grass and legume stands when reclaiming coal strip mines have not been evaluated in northwest Colorado. Nitrogen $(0,28,56$, and 112 $\mathrm{kgN} / \mathrm{ha}$ ) and phosphorus (0 and $56 \mathrm{kgP} / \mathrm{ha}$ ) were applied in all combinations to the spoils before topsoiling or to the surface after topsoiling. In the greenhouse, herbage yield and yield of roots in the $28 \mathrm{~cm}$ of topsoil replaced over the spoil increased as rate of $\mathrm{N}$ increased; phosphorus did not increase yield. Nitrogen content of the herbage increased from $1.02 \%$ to $1.33 \%$ as rate of $\mathrm{N}$ increased from 0 to $112 \mathrm{kgN} / \mathrm{ha}$. In a field study in northwest Colorado, neither $\mathbf{N}$ nor $\mathbf{P}$ fertilizer improved stand establishment ratings. Both the amount and placement of $N$ at time of seeding affected herbage yield during the third growing season. Alfalía yields were increased $20 \%$ by buried $P$ and $44 \%$ by surface $P$ in the third growing season. Applying $\mathbf{N}$ fertilizer at time of seeding is not recommended.
\end{abstract}

Nitrogen $(\mathrm{N})$ deficiency is believed to be a limiting factor in obtaining a productivity level for reclaimed strip mined lands that is comparable to that of the premining plant communities (Woodmansee et al. 1979). On leveled mine spoils in North Dakota, wheat (Triticum aestivum $\mathrm{L}$.) grain yields increased with increasing topsoil depth, but $\mathbf{N}$ fertilization did not increase yields because adequate $\mathbf{N}$ was already present in the topsoil material (Bauer et al. 1978). DePuit and Coenenberg (1979) reported that increased application rates of both $\mathrm{N}(0$ to $121 \mathrm{~kg} / \mathrm{ha})$ and phosphorus $(\mathrm{P})(0$ to $41 \mathrm{~kg} / \mathrm{ha}$ ) fertilizer tended to promote the establishment of introduced grasses at the expense of the less competitive native grasses in a study in eastern Montana. Estimating $\mathbf{N}$ or $\mathbf{P}$ requirements from chemical tests is difficult because laboratory data have not been substantiated by field trials (Berg 1978). This is particularly true in the semiarid West. Forage production of older seeded stands on rangeland can frequently be increased by fertilizing with N (McGinnies 1968), but the need for fertilizer to establish seeded stands for mined land reclamation is not documented, although current regulations (both federal and most states) require that nutrients and soil amendments be applied to the redistributed topsoil before seeding in amounts determined by soil tests so that it supports the postmining land use (U.S. Government 1985).

The authors (unpublished) have observed that relatively small amounts of $\mathbf{N}$ fertilizer applied to established seeded stands on either topsoil or spoil produced substantial increases in herbage yield. This would indicate that the moisture availability is sufficient for the mature plants to make use of more nitrogen than is available in the soil. The question is whether or not seedlings also could take advantage of additional $\mathbf{N}$ fertilizer, and, if so, would this result in a denser or more vigorous stand of seedlings.

This study was conducted to determine the effects of fertilizer on establishment of seeded stands on surface coal mines in northwest Colorado and to determine if fertilizer is necessary for successful establishment. The effects of $\mathbf{N}$ and $\mathbf{P}$ fertilizer on establishment and growth of seeded species in the greenhouse and in the field were

\footnotetext{
Authors are range scientist, USDA, ARS, Crops Research Laboratory, Fort Collins, Colorado 80523; and supervisor, Environmental Services, Getty Oil Company. Oak Creek, Colorado.

Cooperative investigations of USDA, ARS, Fort Collins, Colorado; Colorado Yampa Coal Company, Steamboat Springs, Colorado; and Colorado Agricultural Experiment Station, Colorado State University, Fort Collins. Published with approval of the Director of the Colorado Agricultural Experiment Station.

Manuscript accepted 27 June 1985.
}

studied.

\section{Methods}

The field study was conducted at Energy Mine No. 1 owned by Colorado Yampa Coal Company (formerly Energy Fuels Corporation) located $32 \mathrm{~km}$ southwest of Steamboat Springs, Colo. Soil and spoil materials for the greenhouse study were obtained at the same site. Elevation was $2,250 \mathrm{~m}$, and long-term average annual precipitation was $410 \mathrm{~mm}$. The soil was a Routt loam (fine montmorillonitic Typic Argiboroll). The topsoil was from the A horizon which developed under sagebrush (Artemisia tridentata Nutt.) -mountain brush vegetation. Spoils were from the Williams Fork Formation of the Upper Cretaceous Mesa Verde group which consisted of mixed beds of shale and sandstone. The spoils used in these studies were a heterogeneous mixture of material from the various strata; mixing occurred during removal of the overburden and leveling of the spoil piles. Samples of soil and spoil were analyzed for nitrogen by a Kjeldahl procedure (Bremner 1965), and a bicarbonate extraction was used for determination of phosphorus (Olsen et al. 1954). Electrical conductivity (EC), sodium, calcium, and magnesium were measured on the saturation paste extract, and $\mathrm{pH}$ was measured on the saturated paste (Richards 1954). Particle size distribution was determined by the hydrometer method (Day 1945). Nitrate- $\mathrm{N}$ and organic matter analyses were made by Colorado State University Soils Testing Laboratory.

\section{Greenhouse Study}

Galvanized metal (stove) pipes $15 \mathrm{~cm}$ diam by $61 \mathrm{~cm}$ and closed at the bottom with a wood plug were used as pots for growing plants. Twenty-five $\mathrm{cm}$ of spoil was placed in the bottom of each can and $28 \mathrm{~cm}$ of topsoil was added to give a topsoil-over-spoil growth medium. Spoil material was passed through a $1.3-\mathrm{cm}$ mesh screen before putting it in the cans to eliminate the large rock materials common to spoils.

Fertilizer treatments were applied to the spoil before the topsoil was placed in the pot (buried treatment). Fertilizer treatments, based on surface area of the pots, were:

None
$28 \mathrm{~kg} \mathrm{~N} / \mathrm{ha}$
$56 \mathrm{~kg} \mathrm{~N} / \mathrm{ha}$
$112 \mathrm{~kg} \mathrm{~N} / \mathrm{ha}$
$56 \mathrm{~kg} \mathrm{P} / \mathrm{ha}$
$28 \mathrm{~kg} \mathrm{~N}+56 \mathrm{~kg} \mathrm{P} / \mathrm{ha}$
$56 \mathrm{~kg} \mathrm{~N}+56 \mathrm{~kg} \mathrm{P} / \mathrm{ha}$
$112 \mathrm{~kg} \mathrm{~N}+56 \mathrm{~kg} \mathrm{P} / \mathrm{ha}$

Nitrogen was applied as ammonium nitrate and $P$ as treble superphosphate. Because all fertilizer treatments were both buried and surface, a total of 16 treatments was used. The surface fertilizer treatment was applied after seeding.

Ten seeds were planted in each pot at a depth of $1.5 \mathrm{~cm}$. Three species, intermediate wheatgrass (Agropyron intermedium (Host) Beauv.), slender wheatgrass ( $A$. trachycaulum (Link) Malte), and smooth brome (Bromus inermis Leyss.), were planted with 1 species per pot. The experiment was a randomized complete block design with 4 replications. Planting was on $8 \mathrm{Feb}$. 1979. On 22 March, the seedlings were thinned to 3 per pot. Water was applied 1 to 4 times per week as needed to maintain adequate soil moisture. Temperature in the greenhouse averaged about $22^{\circ} \mathrm{C}$. Sunlight was 
augmented with high pressure sodium vapor lights; day length was $14 \mathrm{hr}$.

Herbage was harvested on $12 \mathrm{Apr}$. and $29 \mathrm{May}$; the herbage was oven-dried at $60^{\circ} \mathrm{C}$ and the weights of the 2 harvests combined. After the second herbage harvest, the pots were split open and the soil washed from the roots. Root material was partitioned into that part which had been growing in topsoil and that part growing in the spoil. Herbage (second cutting only) and root material were analyzed for N (Isaac and Johnson 1976) and P (Technicon Industrial Systems 1976) content.

All data were evaluated using standard analysis of variance or linear correlation techniques.

\section{Field Study}

The plots, 3.66 by $3.66 \mathrm{~m}$ in size, were established on leveled spoil material in September 1978. Fertilizer for the "buried" treatments was applied directly on the spoil material. Topsoil from a stockpile was then spread to a depth of $30 \mathrm{~cm}$ over the spoil and fertilizer, and the plots were restaked. The surface fertilizer treatments were applied after topsoiling and seeding. Fertilizer treatments and sources for both buried and surface treatments were the same as for the greenhouse study.

Rows $3.66 \mathrm{~m}$ long and $30 \mathrm{~cm}$ apart and each containing a single species were drill-seeded on 3 Oct. 1978 to a depth of $2 \mathrm{~cm}$ at a rate of about 100 seeds $/ \mathrm{m}$ of row to 'Critana' thickspike wheatgrass (Agropyron dasystachyum (Hook.) Scribn.), 'Whitmar' beardless wheatgrass ( $A$. spicatum (Pursh) Scribn.), 'Arriba' western wheatgrass (A. smithii Rydb.), 'Regar' meadow brome (Bromus biebersteinii Roem and Schult), 'Lincoln' smooth brome, tall fescue (Festuca arundinacea Schreb.), timothy (Phleum pratense L.), 'Ladak' alfalfa (Medicago sativa $\mathrm{L}$.), and 'Lutana' cicer milkvetch (Astragahuscicer L.). Legumes were inoculated with appropriate rhizobia.

Stand evaluations were made in July 1979, 1980, and 1981. Establishment of the seeded species was evaluated using a stand rating scheme of 0 to $100 \%$ where $100 \%$ was a solid stand of plants in the seeded row, or the maximum stand that could be expected on this site. On 21 July 1981, herbage production was measured by harvesting, oven drying, and weighing a $61-\mathrm{cm}$ length of row that was representative of each seeded row.

The experiment was a randomized complete block design with 3 replications. Data were evaluated by analyses of variance and linear correlation techniques.
Table 1. Physical and chemical characteristics of spoil and topsoil used in field and greenhouse studies.

\begin{tabular}{lcc}
\hline \hline & Spoil & Topsoil \\
\hline Sand (\%) & 19 & 13 \\
Silt $(\%)$ & 39 & 44 \\
Clay (\%) & 42 & 43 \\
Textural Class & Clay & Silty clay \\
Kjeldahl-N $(\mu \mathrm{g} / \mathrm{g})$ & 998 & 951 \\
NOa-N $(\mu \mathrm{g} / \mathrm{g})$ & 5.2 & 6.7 \\
P $(\mu \mathrm{g} / \mathrm{g})$ & 7.2 & 13.7 \\
Organic matter (\%) & 5.51 & 3.1 \\
pH & 6.3 & 5.9 \\
Electrical Conductivity (EC) (S/m) & 0.198 & 0.062 \\
Sodium Adsorption Ratio (SAR) & 0.30 & 0.18 \\
Na (meq/1) & 0.83 & 0.32 \\
Ca (meq/1) & 9.60 & 4.73 \\
Mg (meq/l) & 5.33 & 1.62 \\
\hline
\end{tabular}

'Sample probably contained coal fragments which produced this high value.

\section{Results and Discussion}

Examination of the soil physical and chemical analyses revealed nothing that would restrict germination or growth of the seeded species (Table 1). The Colorado Mined Land Reclamation Division has recommended that the "Guide to Fertilizer Recommendations in Colorado" (Soltanpour 1978) should be consulted for fertilizer requirements. This guide states that if soil organic matter exceeds $2 \%$ on native and improved range grass dryland sites, no additional fertilizer $\mathbf{N}$ need be added, and that when soil test $\mathbf{P}$ exceeds $7 \mu \mathrm{g} / \mathrm{g}$, no fertilizer $\mathrm{P}$ is recommended for dryland alfalfa. The topsoil used in this study exceeds these values for both organic matter and $\mathbf{P}$. Much of the nitrogen in the mine spoil material may be unavailable for plant growth (Reeder and Berg 1977), and the high organic matter value for the spoil resulted from coal fragments in the spoil. The $P$ levels may be slightly low but no evidence of $\mathbf{P}$ deficiencies have been observed in plants growing on either spoil or topsoil. Core samples from the overburden were taken before mining and analyzed for heavy metals, and no excesses were found (Colorado Yampa Coal Company, unpublished data). The

Table 2. Effect of four levels of nitrogen on oven dry herbage and root biomass production ( 8 ) of three grasses grown in a greenhouse in $25 \mathrm{~cm}$ topsoil on top of $28 \mathrm{~cm}$ mine spoil material. (Average of buried and surface treatments).

\begin{tabular}{|c|c|c|c|c|c|}
\hline Plant part & Level of $\mathbf{N}^{1}$ & Intermediate wheatgrass & Smooth brome & Slender wheatgrass & Mean \\
\hline \multirow[t]{2}{*}{$\overline{\text { Herbage }}$} & $\begin{array}{r}0 \\
28 \\
56 \\
112\end{array}$ & $\begin{array}{r}7.6 \\
8.8 \\
10.2 \\
11.3\end{array}$ & $\begin{array}{l}10.5 \\
12.1 \\
12.7 \\
13.9\end{array}$ & $\begin{array}{l}14.7 \\
15.0 \\
19.3 \\
19.5\end{array}$ & $\begin{array}{l}10.92 \\
12.0 \\
14.1 \\
14.9\end{array}$ \\
\hline & Mean & $9.5^{3}$ & 12.3 & 17.1 & 13.0 \\
\hline \multirow[t]{2}{*}{ Roots } & $\begin{array}{r}0 \\
28 \\
56 \\
112\end{array}$ & $\begin{array}{l}7.5 \\
6.2 \\
6.7 \\
7.7\end{array}$ & $\begin{array}{l}3.5 \\
4.0 \\
4.8 \\
4.8\end{array}$ & $\begin{array}{l}2.0 \\
2.2 \\
2.8 \\
3.1\end{array}$ & $\begin{array}{l}4.3^{4} \\
4.1 \\
4.8 \\
5.2\end{array}$ \\
\hline & Mean & $7.0^{5}$ & 4.3 & 2.5 & 4.6 \\
\hline \multirow[t]{2}{*}{ Roots in spoil } & $\begin{array}{r}0 \\
28 \\
56 \\
112\end{array}$ & $\begin{array}{l}2.3 \\
2.8 \\
2.6 \\
3.0\end{array}$ & $\begin{array}{l}1.6 \\
1.7 \\
2.0 \\
2.0\end{array}$ & $\begin{array}{l}0.8 \\
0.7 \\
1.1 \\
0.9\end{array}$ & $\begin{array}{l}1.6^{6} \\
1.7 \\
1.9 \\
2.0\end{array}$ \\
\hline & Mean & $2.7^{7}$ & 1.8 & 0.9 & 1.8 \\
\hline
\end{tabular}

I Kg N/ha

${ }^{2} \mathrm{SD}_{0.01}$ for column means $=1.1$

${ }^{3} L S D_{0.01}$ for row means $=0.9$

${ }^{4} \mathrm{LSD}_{0.01}$ for column means $=0.8$

'LSD 0.01 for row means $=0.7$.

-LSD for column means $=$ NS

${ }^{7} \mathrm{LSD}_{0.01}$ for row means $=0.4$ 
general character and productivity of the pre-mining native vegetation was a further indication of the suitability of the topsoil as a plant growth medium, but the authors (unpublished) observed that small amounts of $\mathbf{N}$ fertilizer applicd to established seeded stands increased herbage yield and plant cover in spite of soil tests that indicated no additional fertilizer was needed.

\section{Greenhouse Study}

No seedling counts were made, but there were no obvious differences in number of seedlings emerged that could be related to fertilizer levels.

There were no significant differences in herbage yield or root production that could be attributed to $P$ application or to fertilizer placement (surface or buried). Herbage yield and root production of all species tended to increase as rate of $\mathbf{N}$ increased (Table 2). Correlation coefficients between rate of $\mathrm{N}$ and herbage yield, and rate of $\mathrm{N}$ and root production were 0.93 and $0.58(p<0.05)$, respectively. Herbage yield and root production also differed significantly $(p<0.01)$ among species. Root production of slender wheatgrass in both topsoil and spoil was low compared to that of the other two species; this agreed with previous findings (Nicholas and McGinnies 1982). The relative increase in herbage production resulting from $\mathbf{N}$ was greater for intermediate wheatgrass than for the other two species; this interaction was significant $(p<0.01)$. Nitrogen content of the herbage increased from $1.0 \%$ to $1.3 \%$ as rate of $\mathrm{N}$ application increased from 0 to $112 \mathrm{~N} / \mathrm{ha}(r=0.82$, $p<0.01$ ). Neither $\mathrm{N}$ conent of the roots nor $\mathrm{P}$ content of herbage or roots were significantly influenced by $\mathbf{N}$ or $\mathbf{P}$ fertilizer.

\section{Field Study}

No germination was observed before a continuous snow cover occurred in autumn 1978. Within a few days after the snow melted in the spring of 1979 , seedlings of most species emerged. Growing conditions during this early spring period were generally favorable for germination and seedling growth. During the first year, meadow brome, tall fescue, and timothy produced the best stands and the largest plants. Stands and growth of the two legumes were poorer than expected on this site, but they appeared to be heavily utilized by jackrabbits (Lepus californicus) and insects.

There were no significant overall effects of $N$ or $P$ on stand establishment. The authors (unpublished) have observed that higher levels of $\mathrm{N}$ sometimes have the effect of increasing abundance and growth of annual weeds which, in turn, compete strongly with the seedlings of the seeded species. Close observation indicated that there was no increase in numbers or production of annual weeds that was related to rate or kind of fertilizer; weed density was not high and growth was relatively uniform over the entire study area. Weeds did not appear to be a serious threat to establishment of the seeded species. Fertilizer did not appear to increase size or vigor of the seedlings, but any effects may have been partly masked by rodent and rabbit utilization of the seeded species. Herbage yield in 1981 was significantly $(p \leqq .05)$ affected by level of $N$ and and by placement of $N$ (Table 3). Placing the fertilizer on the spoil before topsoiling resulted in $15 \%$ lower yields than when the fertilizer was applied to the surface of the topsoil.

Table 3. Herbage yield ( $\mathrm{g} / \mathrm{m}$ of row) as affected by level and placement of nitrogen ( $N$ ) fertilizer on field study plots.

\begin{tabular}{|c|c|c|c|}
\hline \multirow{2}{*}{$\begin{array}{l}\text { Level of } \mathrm{N} \\
(\mathrm{kg} / \mathrm{ha})\end{array}$} & \multicolumn{2}{|c|}{ Fertilizer placement } & \multirow[b]{2}{*}{ Mean ${ }^{1}$} \\
\hline & Surface & Buried & \\
\hline 0 & 82 & 67 & 74 \\
\hline 28 & 102 & 97 & 100 \\
\hline 56 & 96 & 72 & 84 \\
\hline 112 & 92 & 87 & 89 \\
\hline Meañ $^{2}$ & 93 & 81 & 87 \\
\hline
\end{tabular}

$\mathrm{LSD}_{0.06}=16$

${ }_{2}^{2} \operatorname{LSD}_{0.06}=11$
Because roots readily grew into the spoil under the topsoil, it is assumed that the $\mathrm{N}$ fertilizer placed on the spoil was leached downward in the early spring when both soil and spoil are completely saturated with water from snowmelt. Fertilizer applied to the surface of the topsoil was apparently somehow tied up in the topsoil and prevented from leaching. The effects of rate of $\mathrm{N}$ on yield were erratic, and this is attributed to experimental errors. Phosphorus did not affect herbage yield except for alfalfa. Buried $P$ increased herbage yield of alfalfa $20 \%$ and surface applied $P$ increased alfalfa yield $44 \%$.

Stand ratings for 1979,1980, and 1981 are shown in Table 4. These ratings are averages for all rates of fertilizer. There was no significant interaction between fertilizers and species. Although $P$ increased yields of alfalfa significantly, $P$ did not increase stand establishment of alfalfa. No species produced better stands because

Table 4. Stand ratings and oven dry herbage yields of 9 species planted in the fall 1978, in northwest Colorado. (A verage of all fertilizer treatments).

\begin{tabular}{lccccc}
\hline & \multicolumn{3}{c}{ Stand Rating $(\%)$} & & \multicolumn{2}{c}{$\begin{array}{c}\text { Yield } \\
\text { (g/m of row })\end{array}$} \\
\cline { 2 - 3 } \cline { 6 - 6 } Species & 1979 & 1980 & 1981 & & 1981 \\
\hline Meadow brome & 88 & 88 & 90 & 138 \\
Tall fescue & 85 & 76 & 65 & & 48 \\
Timothy & 74 & 75 & 73 & & 77 \\
Alfalfa & 47 & 45 & 63 & 105 \\
Smooth brome & 46 & 56 & 68 & 201 \\
Beardless wheatgrass & 41 & 57 & 60 & 71 \\
Cicer milkvetch & 41 & 24 & 29 & 17 \\
Western wheatgrass & 36 & 36 & 45 & 70 \\
Thickspike wheatgrass & 28 & 36 & 46 & 57 \\
LSD & 7 & 7 & 7 & 16 \\
\hline
\end{tabular}

of $\mathbf{N}$ fertilizer. Stands of tall fescue and cicer milkvetch declined between 1979 and 1981 . There was no known reason for the decline in tall fescue, but the decline in cicer milkvetch is probably a direct result of heavy utilization by rodents and rabbits. Stands of alfalfa, smooth brome, and beardless, western and thickspike wheatgrass all improved. All of these species had less than full initial stands, so the improvement is not surprising. Stands that rated $60 \%$ or above would be classed as "good" and those rating $90 \%$ or above would be "excellent." Good and excellent stands are generally adequate to suppress excessive growth of annual weeds and to provide satisfactory erosion control after the second or third growing season.

There was a linear relationship $(r=0.64, p<0.05)$ between stand rating and herbage yield (Table 4). Tall fescue, timothy, and beardless wheatgrass had stand ratings of 60 or above but were below average in herbage yield. Meadow brome, while not the highest yielding species, has been an outstanding species during the 3 years of this study. The high yield of smooth brome may in part be due to its having less than a full stand. The more open stand $(68 \%)$ permitted the individual plants to produce much more herbage than if they had been growing more densely in the rows. In 1981, smooth brome was the tallest of all species. Herbage yields of alfalfa and cicer milkvetch were reduced because of utilization by mule deer and rodents.

\section{Conclusions}

Federal regulations require that "Nutrients and soil amendments in the amounts determined by soil tests shall be applied to the redistributed surface soil layer, so that it supports the approved postmining land use and meets the revegetation requirements...." before revegetation takes place (U.S. Government 1985). The mined-land-reclamation regulations for Colorado and most other western states contain similar wording. Because fertilizer needs for reclaimed surface mine soils have not been correlated with chemical analyses of the soils, most states have resorted to using predic- 
tive models for fertilizer requirements based on a few results where dryland grass and alfalfa are growing on soils much less disturbed than respread topsoil. The Colorado fertilizer recommendations (Soltanpour 1978) that are used as a guide by the Colorado Mined Land Reclamation Division indicated that no benefit could be expected from adding $\mathbf{N}$ or $\mathbf{P}$ fertilizer, but the recommendations for fertilizing range lands are based on such a few field trials that it would be no surprise if the results we obtained differed greatly from those predicted by the fertilizer recommendations. Although $\mathrm{N}$ did improve yields in this study, there is no reason to put it on at the time of seeding because it did not improve establishment and much of the $\mathrm{N}$ would probably be lost by volatilization and leaching before it could benefit the established plants. Applying $\mathrm{N}$ after the seeded stand becomes established would probably be a better plan. If alfalfa is planted, phosphorus should be applied at or before the time of seeding. Phosphorus increased alfalfa yields in spite of apparently adequate levels of $P$ as determined by chemical tests. In contrast to $N$, very little $P$ is lost from the soil, so it can be applied at or before the time of seeding. Nitrogen fertilizer applied to established seeded stands may provide some benefits in terms of increased ground cover and improved yields. Future research should be directed towards use of fertilizer under such conditions.

\section{Literature Cited}

Bauer, A.P., P. Nyren, G. Riechman, G. Gee, and J. Gilley. 1978. Fertilization of wheat, corn, and a grass-legume mixture grown on reclaimed spoil banks. North Dakota Agr. Exp. Sta. Res. Rep. 67.

Berg, W.A. 1978. Limitations in the usc of soil tests on drastically disturbed lands. p. 653-664. In: F. W. Schaller and P. Sutton (eds.) Reclamation of drastically disturbed lands. Amer. Soc. Agron., Madison, Wis.
Bremner, J.M. 1965. Total nitrogen. p. 1149-1178. In: C.A. Black (ed.) Methods of Soil Analysis, Agron., Monogr. No. 9, Amer. Soc. of Agron., Madison, Wis.

Day, Paul R. 1965. Particle fractionation and particle-size analysis. p. 545-567. In: Methods of Soil Analysis, Agron, Monogr. No. 9, Amer. Soc. of Agron., Madison, Wis.

DePuit, E.J., and J.G. Coenenberg. 1979. Responses of revegetated coal mine spoils to variable fertilization rates, longevity of fertilization program and season of seeding. Montana Agr. Exp. Sta. Res. Rep. 150.

Issuc, R.A., and W.C. Johnson. 1976. Determination of total nitrogen in plant tissue, using a block digestor. J. Ass. Off. Anal. Chem. 59:98-100.

McGinnies, W.J. 1968. Effects of nitrogen fertilizer on an old stand of crested wheatgrass. Agron. J. 60:560-562.

Nicholas, P.J., and W.J. McGinnies. 1982. An evaluation of 17 grasses and 2 legumes for revegetation of soil and spoil on a coal strip mine. J. Range Manage. 35:288-293.

Olsen, S.R., C.V. Cole, F.S. Watanabe, and L.A. Dean. 1954. Estimation of available $\mathrm{P}$ in soils by extraction with $\mathrm{NaHCO}_{3}$. USDA Circ. 939.

Reeder, J.D., and W.A. Berg. 1977. Plant uptake of indigenous and fertilizer nitrogen from a Cretaceous shale and coal mine spoils. Soil Sci. Soc. Amer. J. 41:919-921.

Richards, L.A. 1954. Diagnosis and improvement of saline and alkali soils. Agr. Handb. No. 60, USDA. U.S. Government Printing Office, Washington, D.C.

Soltanpour, P.N. 1978. Guide to fertilizer recommendations in Colorado. Cooperative Extension Service, Colorado State Univ.

Technicon Industrial Systems. 1976. Individual/simultaneous determination of nitrogen and/or phosphorus in BD acid digest, Industrial Method No. 334/74W/B+. Technicon Industrial Systems, Tarrytown, N.Y.

U.S. Government. 1985. Federal Register 30 CFR, Part 816.25.

Woodmansee, R.G., J.D. Reeder, and W.A. Berg. 1979. Nitrogen in drastically disturbed lands. p. 376-392. In. C.T. Youngberg (ed.) Forest soils and land use. Proc. 5th North American Forest Soils Conf., Fort Collins, Colorado, August 1978. Dep. of Forestry and Wood Sci., Colorado State Univ., Fort Collins.
Third Edition

\section{By J. Stubbendieck, Stephan L. Hatch,}

\section{and Kathie J. Hirsch}

Like its predecessors, the third edition of North American Range Plants is a valuable guide to 200 plants that are particularly significant for their abundance, desirability as forage, or noxious properties. Each species description includes nomenclature, life span, origin, season of growth, and inflorescence, vegetative, and growth characteristics. Forage value is estimated, and there are brief notes on habitat, livestock losses, and historical, medicinal, and food uses. Each plant is illustrated in detail, and distribution maps are included. March. $\mathbf{\$ 1 8 . 9 5}$ paper.
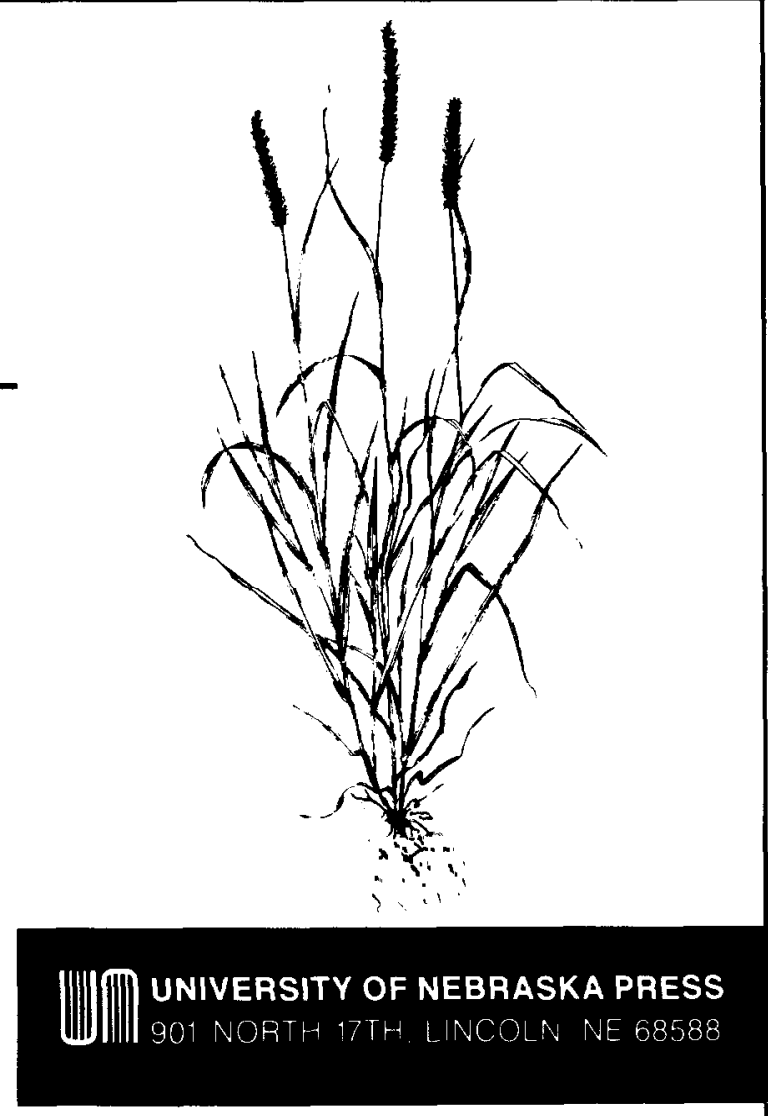